\title{
Characterization of lymphopenia in patients with MS treated with dimethyl fumarate and fingolimod
}

\section{OPEN}

Maryam Nakhaei-Nejad, $\mathrm{PhD}$

David Barilla, Dip Chieh-Hsin Lee, BSc Gregg Blevins, MD Fabrizio Giuliani, MD

Correspondence to Dr. Giuliani: fabrizio.giuliani@ualberta.ca

Supplemental data at Neurology.org/nn

\section{ABSTRACT}

Objective: Lymphopenia is a common occurrence of disease-modifying therapies (DMTs) for relapsing-remitting MS (RRMS). The aim of this study was to dissect the prevalence of various lymphocyte subsets in patients with RRMS treated with 2 DMTs commonly associated with lymphopenia, dimethyl fumarate (DMF), and fingolimod (FTY).

Methods: Multicolor flow cytometry and multiplex assays were used to identify up to 50 lymphocyte subpopulations and to examine the expression of multiple cytokines in selected patients. We compared patients untreated (NT) or treated with FTY or DMF who did (DMF-L) or did not (DMF-N) develop lymphopenia.

Results: All FTY patients developed lymphopenia in both T-cell and B-cell compartments. CD41 T cells were more affected by this treatment than CD81 cells. In the B-cell compartment, the CD271lgD2 subpopulation was reduced. T cells but not B cells were significantly reduced in DMF-L. However, within the B cells, CD271 cells were significantly lower. Both CD41 and CD81 subpopulations were reduced in DMF-L. Within the remaining CD41 and CD81 compartments, there was an expansion of the naive subpopulation and a reduction of the effector memory subpopulation. Unactivated lymphocyte from DMF-L patients had significantly higher levels of interferon- $\gamma$, interleukin (IL)-12, IL-2, IL-4, IL-6, and IL-1 $\beta$ compared with DMF-N. In plasma, TNF $\beta$ was significantly higher in DMF-N and DMF-L compared with NT, whereas CCL17 was significantly higher in DMF-L compared with NT and DMF-N.

Conclusions: This study shows that different treatments can target different lymphocyte compartments and suggests that lymphopenia can induce compensatory mechanisms to maintain immune homeostasis. Neurol Neuroimmunol Neuroinflamm 2018;5:e432; doi: 10.1212/ NXI.0000000000000432

\section{GLOSSARY}

DC = dendritic cell; DMF = dimethyl fumarate; DMT = disease-modifying therapy; FTY = fingolimod; IFN $=$ interferon; IL = interleukin; NT = untreated; NK = natural killer; PBMC = peripheral blood mononuclear cell; PCA = principal component analysis; RRMS = relapsing-remitting MS; $\mathbf{t}$-SNE = t-distributed stochastic neighbor embedding.

Disease-modifying therapies (DMTs) improve the outcome of MS by reducing relapses, number, and volume of lesions. ${ }^{1}$ The mechanisms of action of DMTs involve the reduction of immune activation, which could potentially lead to complications such as lymphopenia, a risk factor for the development of infections. ${ }^{1,2}$ A detailed analysis of the immunologic changes induced by DMTs allows us to identify patients who are at higher risk of developing DMTassociated complications and to gain more insights into the mechanism(s) of the DMTs and pathophysiology of MS.

Dimethyl fumarate (DMF) reduces disease activity through several mechanisms such as induction of apoptosis of activated $\mathrm{T}$ cells, ${ }^{3,4}$ shift of $\mathrm{CD}^{+} \mathrm{T}$ cells toward a Th2 profile, ${ }^{5}$ and reduction of dendritic cell (DC) maturation. ${ }^{6} \mathrm{DMF}$ has been shown to selectively reduce memory T cells in MS and decrease the overall B-cell population, in particular mature B cells. ${ }^{7-9}$

From the Division of Neurology, Department of Medicine, University of Alberta, Edmonton, Canada.

Funding information and disclosures are provided at the end of the article. Go to Neurology.org/nn for full disclosure forms. The Article Processing Charge was funded by the authors.

This is an open access article distributed under the terms of the Creative Commons Attribution-NonCommercial-NoDerivatives License 4.0 (CC BY-NC-ND), which permits downloading and sharing the work provided it is properly cited. The work cannot be changed in any way or used commercially without permission from the journal. 
Fingolimod (FTY), a sphingosine-1receptor antagonist, reduces the egression of lymphocytes from the lymph nodes, with subsequent reduction of the circulating pool of lymphocytes. ${ }^{10}$ FTY-treated patients with MS show a reduction in $\mathrm{T}$ cells and $\mathrm{B}$ cells, as well as changes in the ratio of $\mathrm{T}$ - and B-cell subpopulations. ${ }^{11-17}$

In this study, we characterized the mononuclear cell population of patients who have developed lymphopenia. We developed highdimensional immunophenotyping panels to study various cell surface markers simultaneously at a single cell level and determine the quality of lymphopenia induced by DMF vs FTY.

METHODS Standard protocol approvals, registrations, and patient consents. A total of 55 relapsing-remitting MS (RRMS) patient samples were collected from the Northern Alberta MS Clinic, Alberta, Canada, after approval from the University of Alberta Ethics Committee. Written informed consent was obtained before the blood draw to isolate human peripheral blood mononuclear cells (PBMCs) in accordance with the Ethics Committee recommendations.

Flow cytometry. All antibodies and reagents were purchased from BD Biosciences (Mississauga, ON). One hundred microliters of blood was mixed with freshly made antibody cocktails, no later than 6 hours from the time of collection (stored at room temperature). Clone and product numbers of antibodies are indicated in table e-1 (links.lww.com/NXI/A16). Red blood cells are then lysed using 1XPharmLyse (BD FACS lysing solution) according to the instruction manual. Panels were designed based on antigen density and consideration of spillover characteristics of selected fluorochrome conjugates. Stained samples and controls (gating, compensation, fluorescence minus one) were run on a BD LSRFortessa SORP. Data were analyzed using FlowJo (version 10. 3; FlowJo, LLC, Ashland, OR, 2006-2017) and JMP (version 13. 0 ; SAS, Cary, NC, 2017). Results are expressed as a percentage of child to parent gating or as $\%$ of the total cell count over the original PBMC gate. Gating strategies of each panel are shown in figure e-1 (links.lww.com/NXI/A16). To calculate the lymphocyte subpopulation counts, the cell events were divided by the sum of $\mathrm{T}$ - and B-cell events. This ratio was then normalized to lymphocyte absolute counts by multiplying the ratio to the lymphocyte absolute count.

Cytokine assay. Meso Scale Discovery (Rockville, MD) V-PLEX multiplex assay panels table e-2 (links.lww.com/NXI/A16), were used to measure the levels of a number of cytokines in both plasma and cell culture supernatants.

Cryopreserved PBMCs were thawed and allowed to recover overnight in AIM-V medium (Gibco). They were then divided into activated and unactivated cells and plated for 72 hours at equal concentrations, with the activated cells being plated with immobilized CD3 $(4 \mu \mathrm{g} / \mathrm{mL})$ and soluble CD28 $(40 \mathrm{ng} / \mathrm{mL})$. The activated cells were then incubated with phorbol myristate acid (PMA) $(100 \mathrm{ng} / \mathrm{mL})$ and ionomycin $(500 \mathrm{ng} / \mathrm{mL})$ for an additional 5 hours. Cytokine kits were run according to the manufacturer's instructions for plasma samples. Results registering below the detection limits were replaced with half the lower detection limit and those above the detection limit, with 1.5 times the upper limit.

Statistical analysis. All statistical analysis was performed using JMP and presented as mean \pm SD/SEM. A 1-way analysis of variance (ANOVA) test was used to compare 2 or more groups, with the Each Pair, Student $t$ test used for individual pairwise

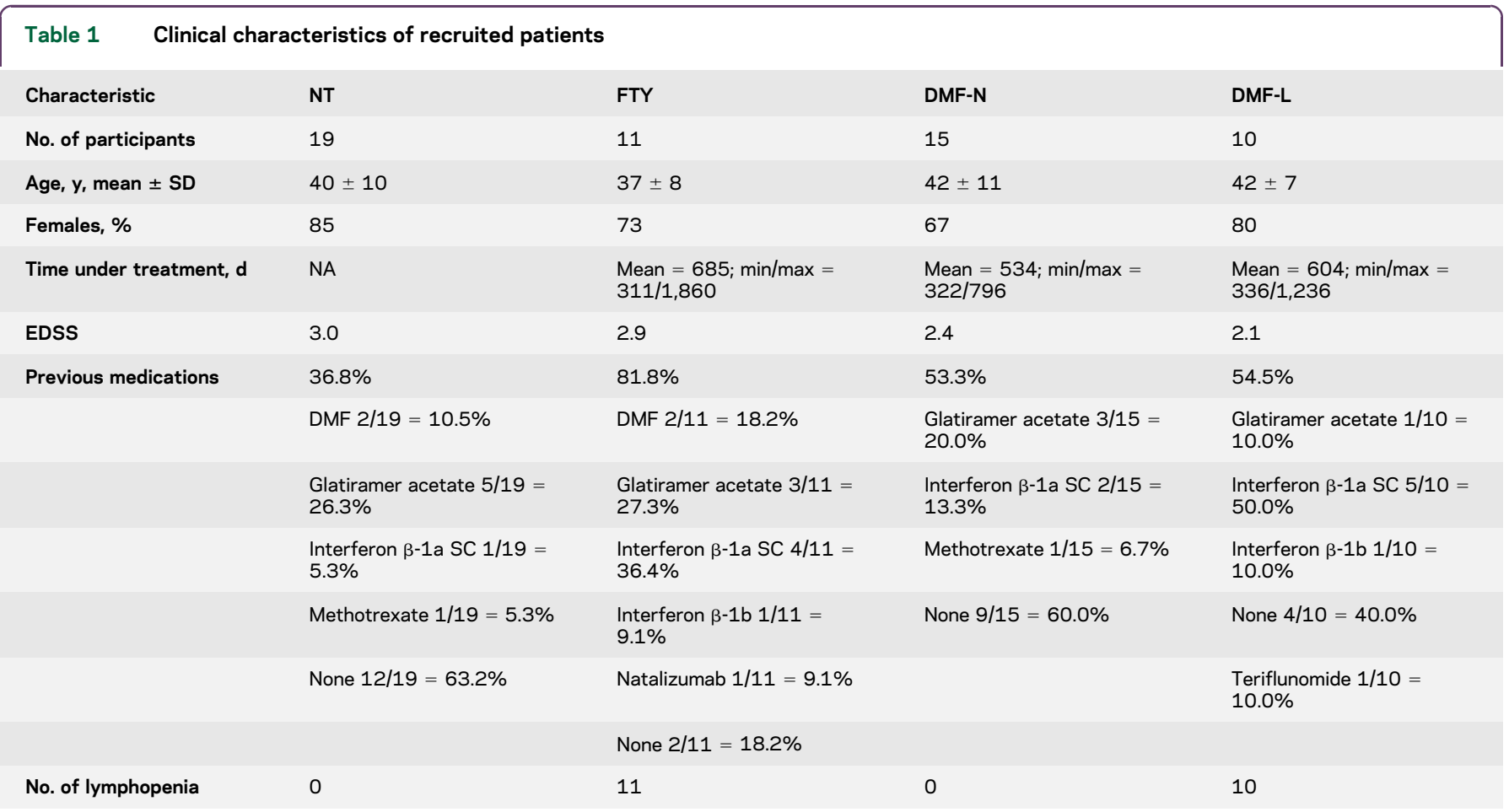

Abbreviations: DMF = dimethyl fumarate; EDSS = Expanded Disability Status Scale; FTY = fingolimod; N/A = not available; NT = untreated; SC = subcutaneous. Demographics of patients with relapsing-remitting MS (NT), FTY-treated patients (FTY), DMF-treated patients with no lymphopenia (DMF-N), and DMFtreated patients who developed lymphopenia (DMF-L) who were recruited for the purpose of immunophenotyping their peripheral blood lymphocytes. 
comparisons between groups. A $p$ value of $<0.01$ was considered statistically significant. Principal component analysis (PCA) was used to reduce the dimensionality, with the proximity on the plots corresponding to the overall similarity between samples. To transform 3D high-dimensional patient data sets into 2D lowdimensional data sets, $\mathrm{t}$-distributed stochastic neighbor embedding (t-SNE) analysis was performed. ${ }^{18}$ For the exploratory analysis of cytokine levels, 1-way ANOVA was performed, followed by Bonferroni tests with a $p$ value of $<0.05$ being considered statistically significant.

RESULTS T-cell subcompartments are differentially affected in lymphopenic DMF- and FTY-treated patients. Table 1 indicates the demographics of the patient populations. According to Common Terminology Criteria for Adverse Events, lymphocyte counts higher than $0.9 \times 10^{\%} / \mathrm{L}$ were considered nonlymphopenic (grade 0$), \leq 0.9 \times 10^{9} / \mathrm{L}$ were scored as grade $1, \leq 0.8 \times 10^{9} / \mathrm{L}$ as grade $2, \leq 0.5 \times 10^{9} / \mathrm{L}$ were scored as grade 3 , and $\leq 0.2$ were scored as grade 4. All patients treated with FTY for more than 1 year developed severe lymphopenia, whereas $40 \%$ of patients treated with DMF more than 1 year developed lymphopenia (figure e-2, links.lww.com/ NXI/A16), allowing for subclassification of the DMF group to DMF-N (nonlymphopenic) and DMF-L (lymphopenic). In our study, only 1 DMFtreated patient developed grade 3 lymphopenia.

We designed 2 multiparametric panels that allowed us to detect the expression of 14 and 17 cell surface markers each (figure e-1, links.lww.com/NXI/A16). The first panel was designed to identify major subpopulations including $\mathrm{T}$ cells, B cells, natural killer (NK) cells, monocytes, and DCs (figure e-1A, links.lww. com/NXI/A16). The second panel focused on different $\mathrm{CD}^{+} \mathrm{T}$-cell subpopulations (figure e-1B, links. lww.com/NXI/A16).

Cell counts indicated that FTY patients have a significant decrease in the overall number of $\mathrm{CD}^{+}$ cells (figure e-3, links.lww.com/NXI/A16). $\mathrm{CD}^{+} \mathrm{CD}^{+}$ cell counts were approximately 95\% lower in FTY patients compared with untreated (NT) patients, while the reduction of $\mathrm{CD}^{+} \mathrm{CD}^{+}$cell counts was not significant (figure e-3, links.lww.com/NXI/A16). $\mathrm{CD}^{+}$cell counts were significantly reduced in DMF-L compared with NT patients, with significant reductions in both $\mathrm{CD}^{+} \mathrm{CD}^{+}$and $\mathrm{CD}^{+} \mathrm{CD}^{+}$populations (figure e3, links.lww.com/NXI/A16, and figure 1, A-C).

Among the remaining $\mathrm{CD}^{+}$cells, there was a significant redistribution of cells regarding CD4 and CD8 expression in patients treated with FTY but not DMF. FTY patients had a significantly higher proportion of $\mathrm{CD}^{-} \mathrm{CD}^{-}$cells within the $\mathrm{CD}^{+}$population compared with all other groups (figure 1D), and the ratio of $\mathrm{CD}^{+}$to $\mathrm{CD}^{+}$cells was significantly lower in FTY patients compared with NT (figure 1E). Both lymphopenic and nonlymphopenic DMF patients had a similar distribution of $\mathrm{CD} 4^{+}$and $\mathrm{CD} 8^{+}$ cells as well as NT patients (figure 1, D and E).

To further characterize peripheral lymphocytes in lymphopenic patients, we looked at the expression of the homing receptors CCR7 and CD62L (L-selectin) in both $\mathrm{CD}^{+}$and $\mathrm{CD}^{+}$cells. The naive population $\left(\mathrm{CD}_{5} 5 \mathrm{RA}^{+} \mathrm{CCR} 7^{+}\right)$within $\mathrm{CD}^{+}$cells was significantly reduced in FTY patients compared with all other groups; however, DMF-L had a higher percent of naive $\mathrm{CD}^{+}{ }^{+}$cells compared with NT and FTY (figure e-4A, links.lww.com/NXI/A16). FTY patients had the highest rate of effector memory cells $\left(\mathrm{CD} 45 \mathrm{RA}^{-} \mathrm{CCR} 7^{-}\right.$) among all groups, with DMF-L having a lower rate compared with NT and FTY (figure e-4A, links.lww.

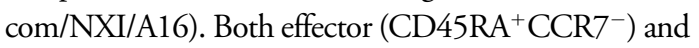
central memory cells $\left(\mathrm{CD}_{4} 5 \mathrm{RA}^{-} \mathrm{CCR} 7^{+}\right)$in $\mathrm{CD}^{+}$ cells did not change significantly in FTY and DMF patients compared with NT; however, DMF patients had significantly lower central memory $\mathrm{CD}^{+}$than FTY-treated ones (figure e-4A, links.lww.com/NXI/ A16). Next, we looked at CD62L vs CD45RA expression. The frequency pattern for CD62L expression in $\mathrm{CD}^{+}$cells was similar to CCR7 expression between groups (figure e-4B, links.lww.com/NXI/A16).

Among the $\mathrm{CD}^{+}$cells, the frequency of naive cells was the lowest in FTY-treated patients compared with all other groups and higher in DMF-L compared with NT and FTY (figure e-4C, links.lww.com/NXI/A16). DMF-L had a lower frequency of effector memory cells in $\mathrm{CD}^{+}$cells compared with NT and FTY. FTY patients had no significant change in the $\mathrm{CD}^{+}$effector memory frequency when compared with NT but had significantly higher levels than both DMF-L and DMF-N (figure e-4C, links.lww.com/NXI/A16). The frequency of effector cells in the $\mathrm{CD}^{+}$population was the highest in FTY, whereas all other groups had a similar frequency of effector cells. The frequencies of central memory cells were not different within groups (figure e-4C, links.lww.com/NXI/A16). $\mathrm{CD} 45 \mathrm{RA}^{+} \mathrm{CD} 2 \mathrm{~L}^{+}$in $\mathrm{CD}^{+}$cells were lowest in FTY-treated patients, whereas DMF-L was not statistically different from NT. Both CD45RA ${ }^{-} \mathrm{CD}_{62} \mathrm{~L}^{-}$ and $\mathrm{CD} 45 \mathrm{RA}^{+} \mathrm{CD} 2 \mathrm{~L}^{-}$frequencies in $\mathrm{CD}^{+}$cells were highest in FTY-treated patients but were not affected by DMF treatment (figure e-4D, links.lww. com/NXI/A16). The $\mathrm{CD}^{+} \mathrm{CD} 45 \mathrm{RA}^{-} \mathrm{CD} 6 \mathrm{~L}^{+}$ population was not significantly different between groups (figure e-4D, links.lww.com/NXI/A16).

The frequency of various $\mathrm{CD}^{+}$subpopulations and the T-cell receptor $\gamma \delta$ are different in lymphopenic DMFtreated patients vs FTY-treated patients. Next, we investigated the frequency of various $\mathrm{T}$-helper subpopulations within the remaining $\mathrm{CD}^{+} \mathrm{T}$ cells in peripheral blood. Although CD119 expression (a marker for Th1-polarized cells) was not significantly 
A

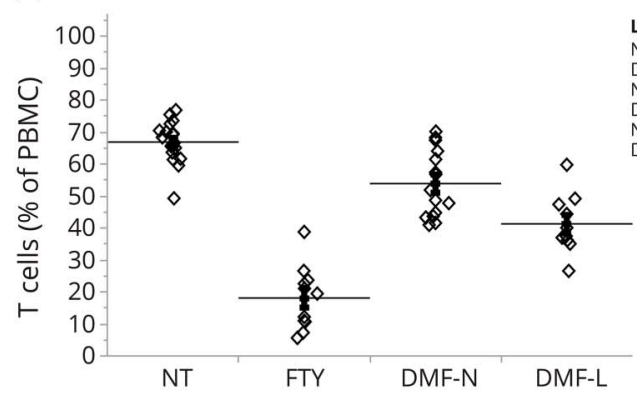

C

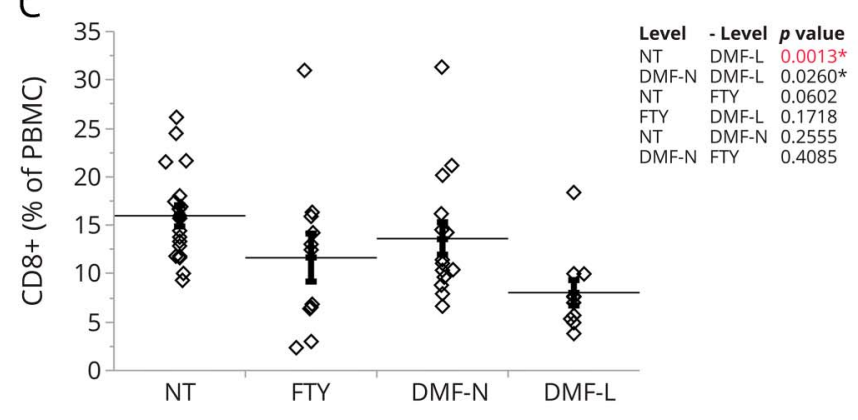

E

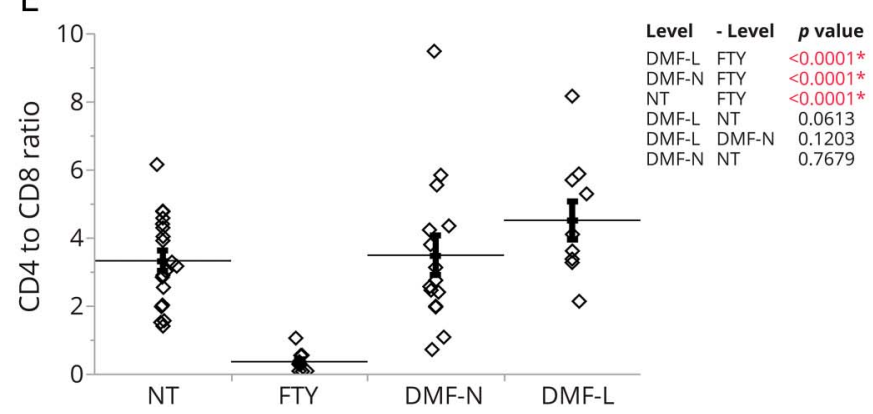

B
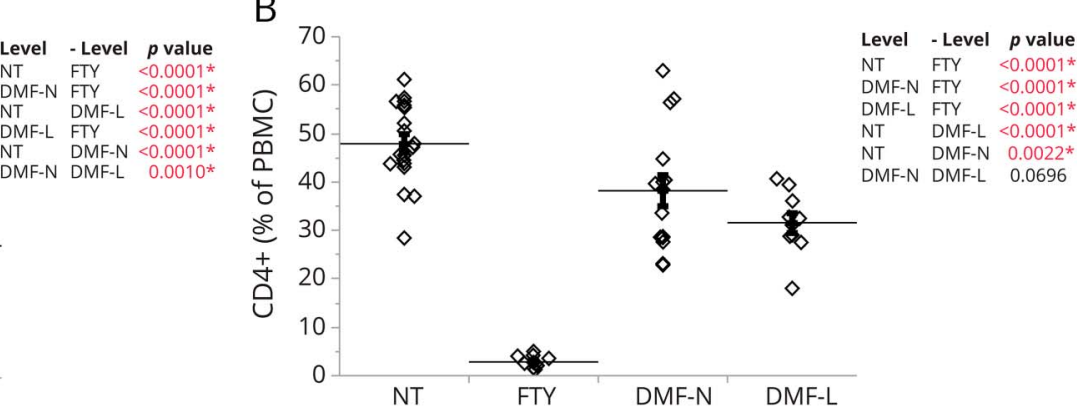

D

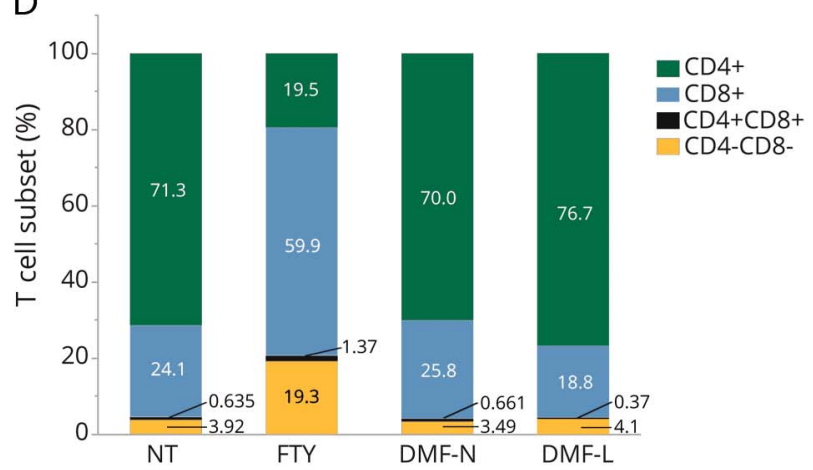

(A) Flow cytometric analysis of the peripheral blood of NT ( $n=19)$, FTY-treated patients (FTY, $n=11)$, DMF-treated patients with no lymphopenia (DMF-N, $n=$ 15), and DMF-treated patients who developed lymphopenia (DMF-L, $n=10$ ) looking at the abundance of $C D 3^{+}(A), C D^{+}(B)$, and $C D 8^{+}(C)$ populations within PBMCs. (D) The frequencies of $\mathrm{CD}^{+}{ }^{+}, \mathrm{CD}^{+}, \mathrm{CD} 4^{-} \mathrm{CD} 8^{-}$, and $\mathrm{CD} 4^{+} \mathrm{CD}^{+}$within the $\mathrm{CD}^{+}{ }^{+}$-cell population (\% of $\mathrm{CD} 3$ ). (E) The ratio of $\mathrm{CD} 4{ }^{+}$to $\mathrm{CD} 8{ }^{+}$cells was calculated using values in D. The horizontal lines indicate the average mean of each group, and the bars are the SEM. $p$ Values are indicated as insets; those reaching statistical significance are highlighted in red. DMF = dimethyl fumarate; FTY = fingolimod; NT = untreated; PBMC = peripheral blood mononuclear cell.

changed between NT and patients treated with DMF or FTY, FTY-treated patients did have a significantly higher proportion of $\mathrm{CD} 119^{+}$cells when compared with both DMF-L and DMF-N (figure 2A). Expression of CRTH2 (CD294), a marker of Th2 phenotype in $\mathrm{CD}^{+}$cells, was not significantly different among the groups (figure $2 \mathrm{~B}$ ). Th17 cells, identified by expression of CD196 (CCR6), were significantly lower in DMF-L compared with NT. FTY-treated patients had a significantly higher fraction of $\mathrm{CD}_{196^{+}}$within $\mathrm{CD}^{+}$cells compared with both DMF-L and DMF-N, whereas no significant changes were detected between FTY and NT (figure $2 \mathrm{C}$ ). The frequency of follicular B-helper $\mathrm{T}$ cells (Tfh) in $\mathrm{CD}^{+}$cells identified by expression of CXCR5 (CD185) was not different among the groups (figure 2D). The fraction of Th22 cells defined by expression of CCR 10 in $\mathrm{CD}_{4}{ }^{+}$cells was significantly higher in FTY-treated patients when compared with all other groups, whereas DMFtreated patients with or without lymphopenia had no significant difference in Th22 frequency (figure 2E). The overall numbers of Th1 and Th17 were significantly reduced in FTY, DMF-N, and DMFL patients when compared with NT (figures e-5A and e-5C, respectively, links.lww.com/NXI/A16). Th2 and Th22 did not significantly change in any of the tested groups (figures e-5B and e-5D, links. lww.com/NXI/A16). Tfh cells had the lowest frequency in the FTY-treated group (figure e-5E, links.lww.com/NXI/A16). Tfh cell numbers were trending toward a decrease in DMF-L compared 

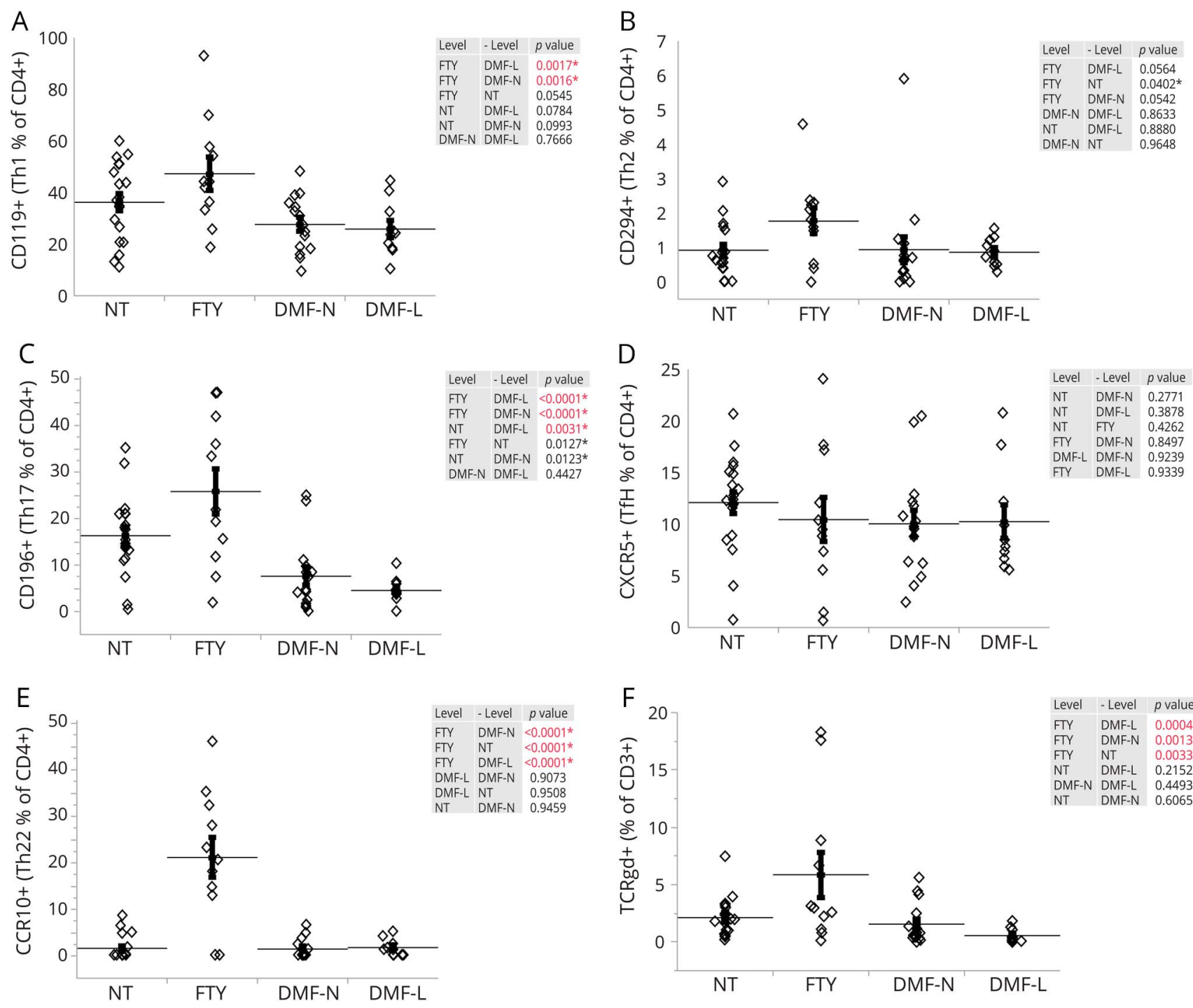

The proportion of Th within $\mathrm{CD} 4^{+}$cells was determined by flow cytometric analysis of peripheral blood for identification of Th1 by CD119+ cells (A), Th2 by

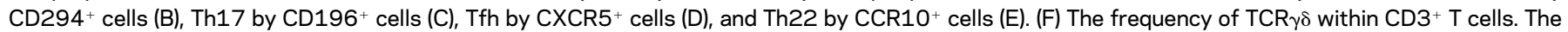
horizontal lines indicate the average mean of each group, and the bars are the SEM. $p$ Values are indicated as insets; those reaching statistical significance are highlighted in red. DMF = dimethyl fumarate; FTY = fingolimod; NT = untreated; PBMC = peripheral blood mononuclear cell.

with NT patients, with DMF-N patients having a significantly lower level (figure e-5E, links.lww. $\mathrm{com} / \mathrm{NXI} / \mathrm{A} 16)$.

Then, we examined the distribution of T-cell receptor $\gamma \delta(\mathrm{TCR} \gamma \delta)$ cells in the same patients. The fraction of TCR $\gamma \delta$ among $\mathrm{CD}^{+}$cells was significantly higher in FTY-treated patients compared with all other groups and unchanged in either DMF-treated patients with or without lymphopenia (figure $2 \mathrm{~F}$ ). The overall number of TCR $\gamma \delta$ was decreased only in DMF-L patients when compared with NT (Figure e-5F, links.lww.com/NXI/A16).

$\mathrm{CD}^{+}{ }^{+} \mathrm{B}$ cells are reduced in FTY-treated patients, and their subpopulations are differentially distributed in both FTY and DMF patients. Next, we sought to determine whether the B cells $\left(\mathrm{CD} 19^{+}\right)$were affected differently in DMF-L patients vs FTY. The DMF-L group had an increase in the overall B-cell compartment in comparison to NT, whereas the overall B-cell count in FTY patients was significantly lower (figure $3 \mathrm{~A}$ and figure e-6, links.lww.com/NXI/A16). Within the $\mathrm{CD} 19^{+}$population, naive and transitional $\mathrm{B}$ cells $\left(\mathrm{CD} 27^{-} \mathrm{IgD}^{+}\right)$had a higher frequency in both DMFtreated groups, whereas FTY-treated patients showed no significant changes compared with NT (figure 3B). Both DMF-treated groups had a lower frequency of preswitch memory cells $\left(\mathrm{CD} 27^{+} \mathrm{IgD}^{+}\right)$when compared with NT, whereas the same subpopulation was not affected in FTY-treated patients (figure 3C). Both FTY and all DMF-treated patients had reduced class-switched memory $\left(\mathrm{CD} 27^{+} \operatorname{IgD}{ }^{-}\right)$frequencies when compared with NT (figure 3D). Classic 


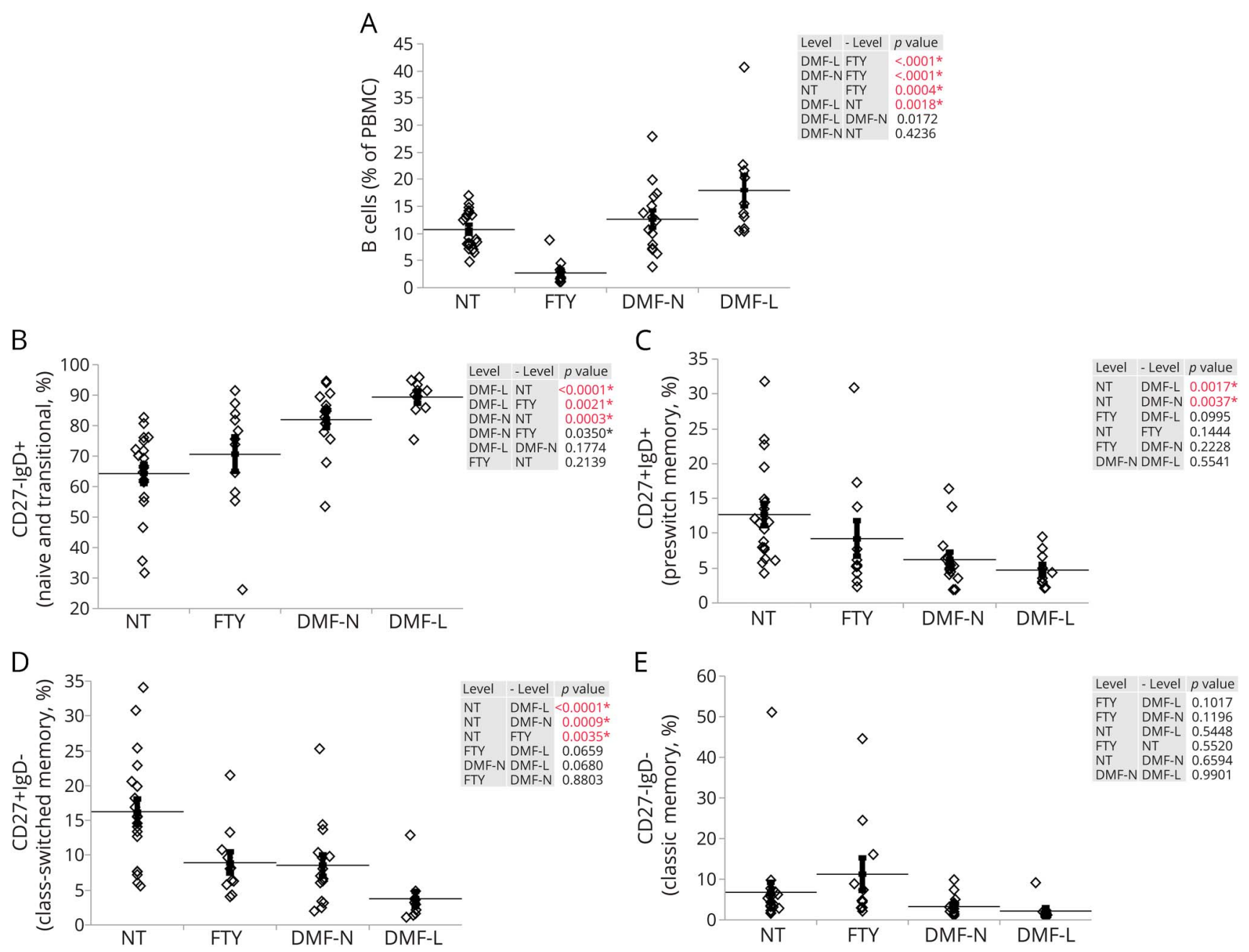

Flow cytometric analysis of the peripheral blood of NT ( $n=19)$, FTY-treated patients (FTY, $n=11)$, DMF-treated patients with no lymphopenia (DMF-N, $n=15)$, and DMF-treated patients who developed lymphopenia (DMF- $L, n=10$ ). (A) Frequency of $B$ cells illustrated as $\%$ of CD19+ cells within PBMCs. The frequency of

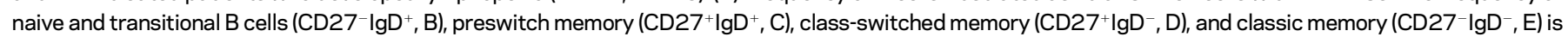
calculated as \% of $\mathrm{CD}_{19} 9^{+}$cells. The horizontal lines indicate the average mean of each group, and the bars are the SEM. $p$ Values are indicated as insets; those reaching statistical significance are highlighted in red. DMF = dimethyl fumarate; FTY = fingolimod; NT = untreated; PBMC = peripheral blood mononuclear cell.

memory B-cell $\left(\mathrm{CD} 27^{-} \mathrm{IgD}^{-}\right)$frequencies were not significantly different between the groups (figure 3E).

The proportion of monocytes, NKs, and DCs is different between DMF- and FTY-treated patients. Next, we aimed at determining whether FTY-treated or DMFL-treated patients have different amounts of other major mononuclear cells: monocytes, NK cells, and dendritic cells (DCs). Monocytes were identified as $\mathrm{CD} 14^{+}$cells within the $\mathrm{CD}^{-}{ }^{-} \mathrm{CD} 19^{-}$population. Both FTY-treated and DMF-L-treated patients had higher amounts of monocytes compared with NT (figure e-7A, links.lww. com/NXI/A16). FTY-treated patients had a higher amount of $\mathrm{NK}$ cells $\left(\mathrm{CD} 3{ }^{-} \mathrm{CD} 19^{-} \mathrm{CD} 56^{+} \mathrm{CD} 16^{+}\right)$ than all other groups, whereas DMF-treated patients had a similar NK frequency compared with NT (figure e-7B, links.lww.com/NXI/A16). FTYtreated patients had a significantly higher
$\mathrm{CD}^{-} \mathrm{CD}^{-} 9^{-} \mathrm{CD} 14^{-} \mathrm{HLA}^{-} \mathrm{Dr}^{+}$(DCs) when compared with all other groups. DMF-L patients also had a higher frequency of DCs within the PBMCs when compared with NT and DMF-N patients (figure e-7C, links.lww.com/NXI/A16).

Lymphopenic DMF patients have a different cytokine profile in comparison to NT and nonlymphopenic DMF patients. To investigate the cytokine profile of lymphopenic patients, we measured the levels of 38 molecules in the plasma and supernatants from PBMCs using a multiplex assay in a subset of NT and DMF-treated patients. Because all the FTY patients developed lymphopenia, they were excluded from the analysis because of the lack of a control group. All cytokine levels are shown in figure e-8 (links.lww.com/NXI/A16). The cytokines with a statistically significant difference 
among NT, DMF-L, and DMF-N are shown in figure 4. In the plasma, TNF $\beta$ was higher in DMF$\mathrm{N}-$ and DMF-L-treated groups when compared with NT (figure 4A). CCL17 was also significantly different between groups, with higher levels in the DMF-L (figure 4B).

To study the function of leukocytes in response to stimulation, we measured the cytokine production by PBMCs of patients with and without activation by
$\mathrm{CD} 3 / \mathrm{CD} 28$. In the unactivated cells, there were significant differences on the levels of interferon (IFN)- $\gamma$, interleukin (IL)-2, IL-6, IL-12p70, IL-4, and IL-1 $\beta$ (figure $4, \mathrm{C}-\mathrm{H}$ ). IFN- $\gamma$ was significantly lower in the DMF-N group (figure 4C). The levels of IL-2, IL-6, IL-12p70, IL-4, and IL-1 $\beta$ were all significantly higher in the DMF-L group than those in the DMF-N group (figure 4, D-H). On activation, all cytokine levels increased; however, no significant

Figure 4 Abundance of cytokines which showed significant difference in expression in the plasma and the cultured PBMC of patients with RRMS

A

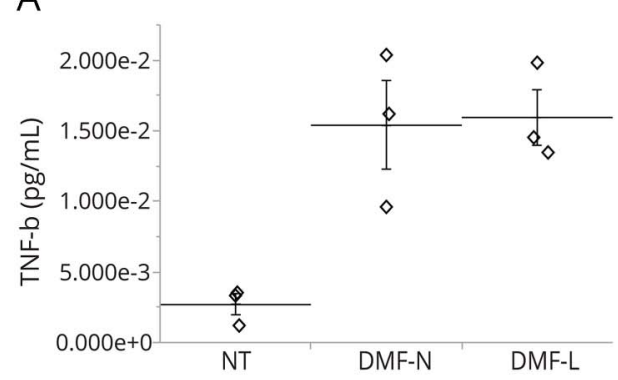

C

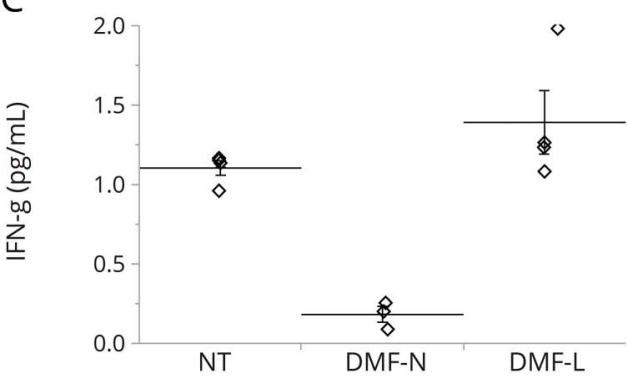

E

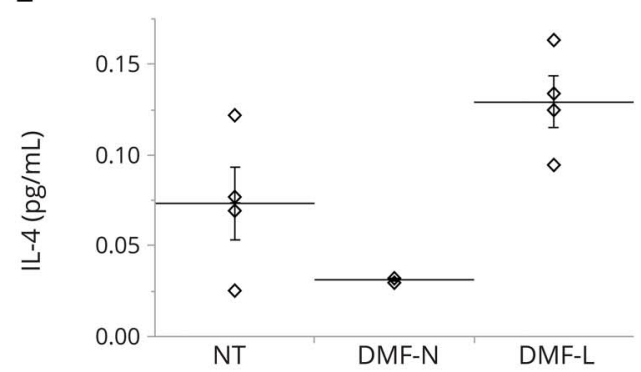

G
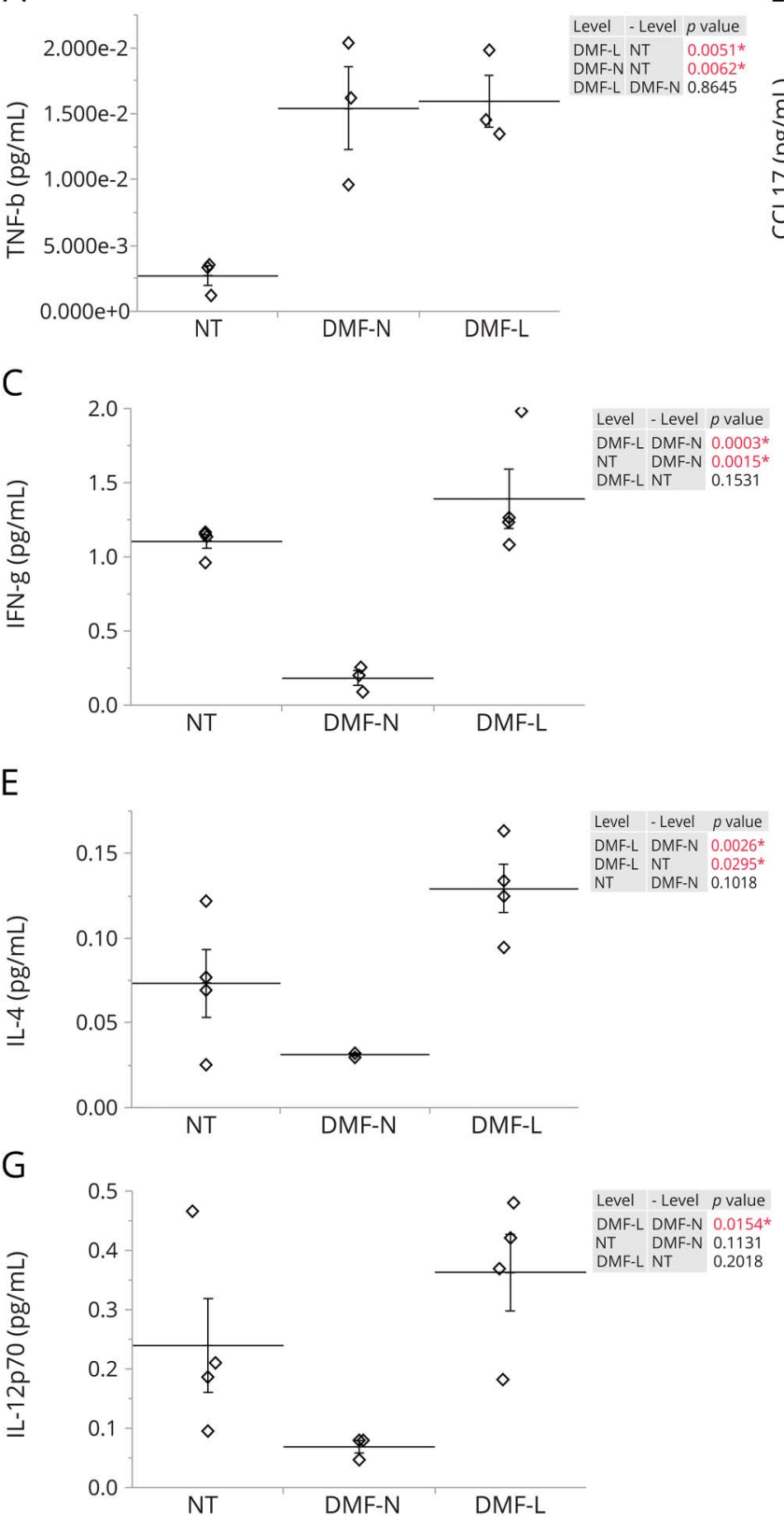

Level - Level $p$ value DMF-L DMF-N $0.0003^{*}$ NT DMF-N 0.0015
B

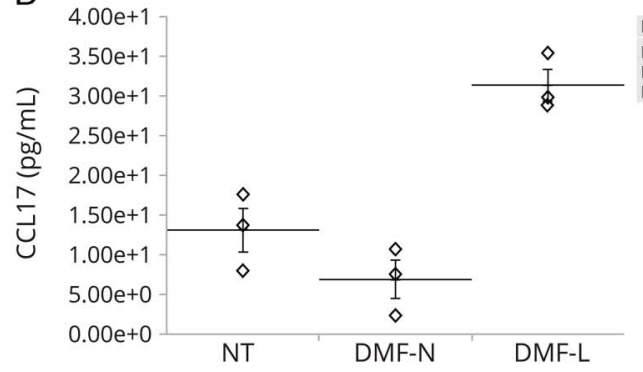

D

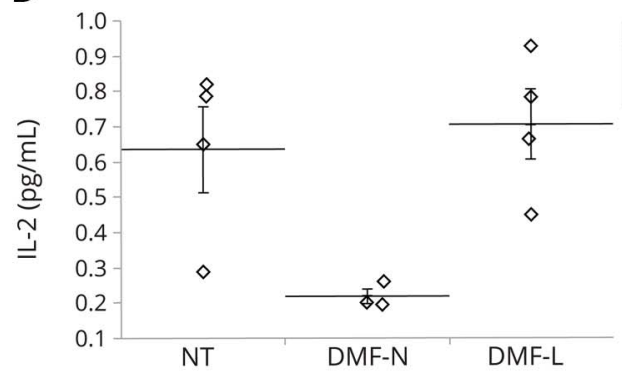

F

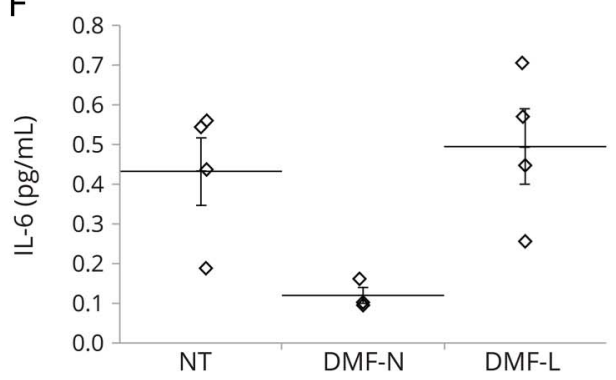

$\mathrm{H}$

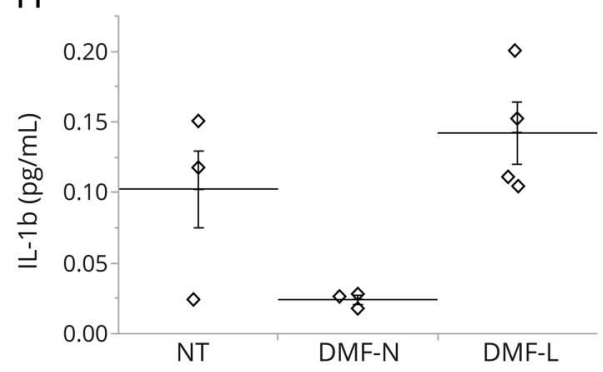

Multiplex cytokine assay analysis of plasma levels of (A) TNF $\beta$ and (B) CCL17. Multiplex cytokine assay analysis was also performed on unactivated PBMC supernatant levels of (C) IFN- $\gamma$, (D) IL-2, (E) IL-4, (F) IL-6, (G) IL-12, and (H) IL-1 $\beta$ for NT ( $n=3$ ), DMF-treated patients with no lymphopenia (DMF-N, $n=3$ for plasma and $n=4$ for supernatants), and DMF-treated patients who developed lymphopenia (DMF-L, $n=3$ for plasma and $n=4$ for supernatants). The horizontal lines indicate the average mean of each group, and the bars are the SEM. $p$ Values are indicated as insets; those reaching statistical significance are highlighted in red. DMF $=$ dimethyl fumarate; FTY = fingolimod; IFN = interferon; IL = interleukin; NT = untreated; PBMC = peripheral blood mononuclear cell; RRMS = relapsing-remitting MS. 
differences were detected among the different groups (figure e-8C, links.lww.com/NXI/A16).

DISCUSSION In this study, we aimed to investigate the changes to the immune compartments of patients with MS treated with DMTs that can potentially induce lymphopenia. In our study, all patients treated with FTY for more than 1 year developed lymphopenia. Our findings contrast with those found in the FREEDOMS II trial that showed approximately $10 \%$ of patients developed lymphopenia after receiving FTY. ${ }^{19}$ This discrepancy might be due to different patient characteristics and possible exposure to previous medications in our population. Our findings showing lymphopenia in DMF patients are consistent with previous reports in which $5 \%$ of patients developed severe lymphopenia. ${ }^{20,21}$

Consistent with previous findings, we detected reduced $\mathrm{CD}^{+}{ }^{-}$and $\mathrm{CD}^{+}{ }^{+}$-naive cells in FTYtreated patients. ${ }^{22,23}$ However, we were not able to detect significant changes in $\mathrm{CD}^{+}$and $\mathrm{CD}^{+}$central memory populations. The reason for this discrepancy is unclear. The disproportionate decrease in the $\mathrm{CD}^{+}$vs $\mathrm{CD}^{+}$subpopulations could be explained by the observation that in NT patients and healthy controls, most $\mathrm{CD}_{2} \mathrm{~L}^{+} \mathrm{T}$ cells are $\mathrm{CD}^{+}$; thus, $\mathrm{CD}^{+}$cells have a higher chance of homing and consequently being trapped into the lymphoid organs (figure e-9, links.lww.com/NXI/A16).

DMF-treated lymphopenic patients had a decreased number of $\mathrm{CD}^{+}$cells, as reported in previous studies. $^{7,24,25}$ In agreement with our observation, Perrone and Williamson ${ }^{26}$ have shown that the $\mathrm{CD}^{+} / \mathrm{CD}^{+}$ cell ratio is increased in DMF patients and decreases rapidly on discontinuation of DMF, although this ratio did not reach statistical significance in our study. Consistent with these findings, a recent study showed that DMF induces apoptosis in $\mathrm{CD}^{+}$cells, affecting $\mathrm{CD}^{+}$more than $\mathrm{CD}^{+}$cells and, within these subpopulations, memory cells more than naive cells. ${ }^{27}$ Unlike Longbrake et al., ${ }^{7}$ we did not detect a significant redistribution of $\mathrm{CD}^{+}$cell subpopulations in DMF-treated patients with no lymphopenia; however, we did detect redistribution of $\mathrm{CD}^{+}$and $\mathrm{CD}^{+}$cells in DMF-treated patients with lymphopenia. In line with previous findings, DMF-L patients had drastically a higher naive population and a lower effector memory population within both $\mathrm{CD}^{+}$and $\mathrm{CD}^{+}$cells. ${ }^{7,27}$ Because it has been shown that $\mathrm{CD}^{+} \mathrm{T}$ cells found in CSF and lesions of patients with RRMS are mostly CD62L effector memory $\mathrm{T}$ cells, depletion of this population in the DMF-L patients could be one of the mechanisms by which DMF reduces MS activity. ${ }^{28}$ However, because the main function of $\mathrm{CD}^{+}$memory cells is to protect against viral infections, low levels of
$\mathrm{CD}^{+}$effector memory and central memory may be an indicator of patients being at risk of developing viral infections and thus needing more frequent monitoring. ${ }^{29}$

In agreement with previous findings, we observed a reduction of Th1 and Th17 cells with both FTY and DMF. ${ }^{7,25,27}$ The role of Th1 and Th17 in inducing MS lesions is well established, and the reduced number of these cells by these treatments could be another way to reduce MS disease activity by FTY and DMF. ${ }^{30,31}$

Consistent with previous observations, we also observed a significant decrease in the B-cell population in FTY-treated patients. ${ }^{13-17}$ Although previous studies have shown significant decreases in both class-switched and non-class-switched memory B cells, our data showed significant changes only in the class-switched memory $\left(\mathrm{CD} 27^{+} \mathrm{IgD}{ }^{-}\right)$compartment. ${ }^{12-14,16}$

Unlike previous studies, we did not observe an overall decrease in $\mathrm{CD} 19^{+} \mathrm{B}$ cells in DMF-treated patients compared with NT.7,9,24 However, we found redistribution of $\mathrm{CD} 19^{+} \mathrm{B}$ cells in DMF-treated patients, with naive and transitional $\left(\mathrm{CD} 27^{-} \mathrm{IgD}^{+}\right) \mathrm{B}$ cells being increased in DMF patients. We also saw an decrease of preswitch memory and class-switched memory B cells in DMF patients. This observation supports the previous findings, showing more severe reduction of memory than naive $B$ cells in vivo and in vitro, by induction of apoptosis in mature B cells by DMF treatment. ${ }^{9}$ The importance of $\mathrm{B}$ cells in MS is highlighted by the success of B-cell depletion drugs in reducing disease activity. Thus, reduction of memory B cells in DMF-treated patients could be another mechanism by which DMF reduces MS activity.

The effect of FTY and DMF on TCR $\gamma \delta$ T cells has not been previously described. TCR $\gamma \delta \mathrm{T}$ cells are considered a link between adaptive and innate immunity because they share functionalities of both systems. ${ }^{32}$ We found that TCR $\gamma \delta \mathrm{T}$ cells were reduced in DMF-treated patients who developed lymphopenia. However, this was an indirect consequence of the decrease in the overall $\mathrm{CD}^{+}$population, suggesting that the effect of DMF is independent of TCR variations. On the other hand, the apparent increase in the FTY-treated patients was related to a decrease in the other T-cell compartments, suggesting no significant effect of FTY on the TCR $\gamma \delta$ T-cell population.

To investigate potential soluble biomarkers of lymphopenia, we analyzed the cytokine profile in a subgroup of patients and found higher levels of circulating TNF $\beta$ and CCL17 in DMF-L patients. CCL17 (also known as thymus and activation regulated chemokine or TARC) is a ligand for CCR4, a receptor expressed on Th17 cell and Tregs. ${ }^{33-35}$ 
CCL17 levels have been shown to correlate with monocyte numbers. ${ }^{36} \mathrm{We}$ also observed a correlation between the fraction of monocytes and amounts of CCL17 in DMF-L patients. CCL17 also plays a role in the trafficking of mature $\mathrm{T}$ cells and their activation and development in the thymus. ${ }^{33}$ TNF $\beta$ (also known as lymphotoxin- $\alpha$ ) has been linked to NK cell proliferation and activity and also has proinflammatory effects. ${ }^{37-39}$ Furthermore, in the supernatant from unactivated cells, the DMF-L group had significantly higher levels of some proinflammatory and regulatory cytokines than the DMF-N group. This increase in cytokine production may be because of a higher activation state in the lymphopenic group induced by compensatory mechanisms to maintain immunity in the face of fewer immune cells. The lack of significant differences in cytokine levels after activation may be due to different factors such as the small sample size or a masking effect related to overactivation.

Computational analysis of high-dimensional data by algorithms such as t-SNE (figure e-10, links.lww.com/NXI/A16), enables us to grasp an overall view of the changes occurring in peripheral blood of patients with and without treatment. ${ }^{18}$ As shown in figure e-10 (links.lww.com/NXI/A16), the overall distribution of PBMC compartments differs between groups. The high throughput data generated in our study may also help us to identify patients at risk of potential complications associated with lymphopenia. For instance, the PCA indicated clustering of patients according to treatment in panel 1 (figure e-11, links.lww.com/NXI/A16). Of interest, patients with the same lymphocyte count cluster differently: RRMS023 and RRMS011 both have a lymphocyte level of 0.9, but RRMS023 clusters with other DMF-L patients, whereas RRMS011 clusters with DMF-N patients. This may be an indicator that although the RRMS023 lymphocyte level is not alarmingly low, the patient might be at risk of developing lymphopenia-related complications (figure e-11, links.lww.com/NXI/A16). Further investigations are currently ongoing in our laboratory to determine this possibility.

Using deep cell surface marker analysis, we have shown that the quality of lymphopenia differs in the patients treated with FTY and DMF with lymphopenia. We have identified CCL17 as a molecule that is expressed differently in DMF-treated patients depending on their lymphocyte count. Whether CCL17 could be a biomarker of lymphopenia warrants further confirmation by a larger sample size. Our data suggest that, in the clinical settings, the lymphocyte count alone may not be an accurate and reliable indicator of the immune changes induced by of DMTs to identify patients at risk of complications.

\section{AUTHOR CONTRIBUTIONS}

Maryam Nakhaei-Nejad: study design and acquisition and analysis of the data. David Barilla and Chieh-Hsin Lee: acquisition and analysis of the data. Gregg Blevins: critical intellectual contribution. Fabrizio Giuliani: study supervision.

\section{ACKNOWLEDGMENT}

The authors thank Aaron Hirschfeld from BD biosciences for his assistance in selection of fluorochrome conjugates for the flow cytometry panels and optimizing antibody concentrations.

\section{STUDY FUNDING}

This study was sponsored by Biogen Idec Canada Inc and Government of Alberta. The funders had no role in preparation of the manuscript.

\section{DISCLOSURE}

M. Nakhaei-Nejad, D. Barilla, and C.-H. Lee report no disclosures. G. Blevins served on the scientific advisory board of Biogen, Teva, Novartis, Genzyme, Roche, and EMD Serono/Merck; received travel funding from Biogen, Teva, Novartis, Genzyme, Roche, and EMD Serono/Merck; consulted for Biogen, Teva, Novartis, Genzyme, Roche, and EMD Serono/Merck; and received research support from the Canadian Institutes of Health Research, Alberta Innovates, the Canadian Foundation for Innovation, and the Multiple Sclerosis Society of Canada. F. Giuliani served on the scientific advisory board of Alberta MS Network; received speaker honoraria from Merck Serono, Biogen, Genzyme, and Roche; consulted for Merck Serono, Biogen, Genzyme, and Roche; and received research support from Biogen Canada and Alberta Ministry of Innovation and Advanced Education. Go to Neurology.org/nn for full disclosure forms.

Received August 17, 2017. Accepted in final form October 3, 2017.

\section{REFERENCES}

1. Wingerchuk DM, Weinshenker BG. Disease modifying therapies for relapsing multiple sclerosis. BMJ 2016;354: i3518.

2. Delgado-Alvarado M, Sedano MJ, González-Quintanilla V, et al. Progressive multifocal leukoencephalopathy and idiopathic CD4 lymphocytopenia. J Neurol Sci 2013;327: 75-79.

3. Höxtermann S, Nüchel C, Altmeyer P. Fumaric acid esters suppress peripheral CD4- and CD8-positive lymphocytes in psoriasis. Dermatology 1998;196:223-230.

4. Treumer F, Zhu K, Gläser R, Mrowietz U. Dimethylfumarate is a potent inducer of apoptosis in human $\mathrm{T}$ cells. J Invest Dermatol 2003;121:1383-1388.

5. de Jong R, Bezemer AC, Zomerdijk TP, et al. Selective stimulation of $\mathrm{T}$ helper 2 cytokine responses by the antipsoriasis agent monomethylfumarate. Eur J Immunol 1996;26:2067-2074.

6. Peng $\mathrm{H}$, Guerau-de-Arellano $\mathrm{M}$, Mehta $\mathrm{VB}$, et al. Dimethyl fumarate inhibits dendritic cell maturation via nuclear factor $\kappa \mathrm{B}(\mathrm{NF}-\kappa \mathrm{B})$ and extracellular signalregulated kinase 1 and 2 (ERK1/2) and mitogen stressactivated kinase 1 (MSK1) signaling. J Biol Chem 2012; 287:28017-28026.

7. Longbrake EE, Ramsbottom MJ, Cantoni C, et al. Dimethyl fumarate selectively reduces memory $\mathrm{T}$ cells in multiple sclerosis patients. Mult Scler 2016;22:10611070.

8. Lundy SK, Wu Q, Wang Q, et al. Dimethyl fumarate treatment of relapsing-remitting multiple sclerosis influences B-cell subsets. Neurol Neuroinflamm Neuroinflammation 2016;3:e211. doi: 10.1212/NXI. 0000000000000211 . 
9. Li R, Rezk A, Ghadiri M, et al. Dimethyl fumarate treatment mediates an anti-inflammatory shift in B cell subsets of patients with multiple sclerosis. J Immunol 2016;198: 691-698.

10. Brinkmann V. FTY720 (fingolimod) in multiple sclerosis: therapeutic effects in the immune and the central nervous system. Br J Pharmacol 2009;158:1173-1182.

11. Mehling M, Brinkmann V, Antel J, et al. FTY720 therapy exerts differential effects on $\mathrm{T}$ cell subsets in multiple sclerosis. Neurology 2008;71:1261-1267.

12. Nakamura M, Matsuoka T, Chihara N, et al. Differential effects of fingolimod on B-cell populations in multiple sclerosis. Mult Scler 2014;20:1371-1380.

13. Blumenfeld S, Staun-Ram E, Miller A. Fingolimod therapy modulates circulating B cell composition, increases B regulatory subsets and production of IL-10 and TGF-beta in patients with multiple sclerosis. J Autoimmun 2016;70:40-51.

14. Miyazaki $Y$, Niino M, Fukazawa T, et al. Suppressed proinflammatory properties of circulating B cells in patients with multiple sclerosis treated with fingolimod, based on altered proportions of B-cell subpopulations. Clin Immunol 2014;151:127-135.

15. Grutzke B, Hucke S, Gross CC, et al. Fingolimod treatment promotes regulatory phenotype and function of $\mathrm{B}$ cells. Ann Clin Transl Neurol 2015;2:119-130.

16. Claes N, Dhaeze T, Fraussen J, et al. Compositional changes of $B$ and $T$ cell subtypes during fingolimod treatment in multiple sclerosis patients: a 12-month follow-up study. PLoS One 2014;9:e111115.

17. Kowarik MC, Pellkofer HL, Cepok S, et al. Differential effects of fingolimod (FTY720) on immune cells in the CSF and blood of patients with MS. Neurology 2011;76: 1214-1221.

18. Van Der Maaten L, Hinton G, van der Maaten GH. Visualizing data using t-SNE. J Mach Learn Res 2008;9: 2579-2605.

19. Calabresi PA, Radue EW, Goodin D, et al. Safety and efficacy of fingolimod in patients with relapsingremitting multiple sclerosis (FREEDOMS II): A doubleblind, randomised, placebo-controlled, phase 3 trial. Lancet Neurol 2014;13:545-556.

20. Fox RJ, Miller DH, Phillips JT, et al. Placebo-controlled phase 3 study of oral BG-12 or glatiramer in multiple sclerosis. N Engl J Med 2012;367:1087-1097.

21. Gold R, Kappos L, Arnold DL, et al. Placebo-controlled phase 3 study of oral BG-12 for relapsing multiple sclerosis. N Engl J Med 2012;367:1098-1107.

22. Chiba K, Yanagawa Y, Masubuchi Y, et al. FTY720, a novel immunosuppressant, induces sequestration of circulating mature lymphocytes by acceleration of lymphocyte homing in rats: I: FTY720 selectively decreases the number of circulating mature lymphocytes by acceleration of lymphocyte homing. J Immunol 1998;160:5037-5044.

23. Brinkmann V, Cyster JG, Hla T. FTY720: sphingosine 1phosphate receptor-1 in the control of lymphocyte egress and endothelial barrier function. Am J Transpl 2004;4: 1019-1025.

24. Spencer CM, Crabtree-Hartman EC, Lehmann-Horn K, et al. Reduction of $\mathrm{CD}^{+} \mathrm{T}$ lymphocytes in multiple sclerosis patients treated with dimethyl fumarate. Neurol Neuroimmunol Neuroinflamm 2015;2:e76. doi: 10.1212/ NXI.0000000000000076.

25. Gross CC, Schulte-Mecklenbeck A, Klinsing S, et al. Dimethyl fumarate treatment alters circulating $\mathrm{T}$ helper cell subsets in multiple sclerosis. Neurol Neuroinflamm Neuroinflammation 2016;3:e183. doi: 10.1212/NXI. 0000000000000183.

26. Perrone C, Williamson E. An examination of lymphocyte subpopulations in MS patients on dimethyl fumarate before and after therapy coupled with analysis of JCV serostatus. Mult Scler J 2017;23:33-34.

27. Ghadiri M, Rezk A, Li R, et al. Dimethyl fumarate-induced lymphopenia in MS due to differential T-cell subset apoptosis. Neurol Neuroimmunol Neuroinflamm 2017;4:e340. doi: 10.1212/NXI.0000000000000340.

28. Ifergan I, Kebir H, Alvarez JI, et al. Central nervous system recruitment of effector memory CD8 $+\mathrm{T}$ lymphocytes during neuroinflammation is dependent on $\alpha 4$ integrin. Brain 2011;134:3560-3577.

29. Wherry EJ, Teichgräber V, Becker TC, et al. Lineage relationship and protective immunity of memory CD8 T cell subsets. Nat Immunol 2003;4:225-234.

30. Annunziato F, Cosmi L, Santarlasci V, et al. Phenotypic and functional features of human Th17 cells. J Exp Med 2007;204:1849-1861.

31. Goverman J. Autoimmune T cell responses in the central nervous system. Nat Rev Immunol 2009;9:393-407.

32. Sree Latha T, Reddy MC, Durbaka PVR, et al. Gamma delta $\mathrm{T}$ cell-mediated immune responses in disease and therapy. Front Immunol 2014;5:571.

33. Imai $\mathrm{T}$, Baba $\mathrm{M}$, Nishimura $\mathrm{M}$, et al. The $\mathrm{T}$ cell-directed CC chemokine TARC is a highly specific biological ligand for CC chemokine receptor 4. J Biol Chem 1997;272: 15036-15042.

34. Acosta-Rodriguez EV, Rivino L, Geginat J, et al. Surface phenotype and antigenic specificity of human interleukin 17-producing T helper memory cells. Nat Immunol 2007; 8:639-646.

35. Butti E, Bergami A, Recchia A, et al. IL4 gene delivery to the CNS recruits regulatory $\mathrm{T}$ cells and induces clinical recovery in mouse models of multiple sclerosis. Gene Ther 2008; 15:504-515.

36. Komatsu-Fujii T, Kaneko S, Chinuki Y, et al. Serum TARC levels are strongly correlated with blood eosinophil count in patients with drug eruptions. Allergol Int 2017; 66:116-122.

37. Kim TJ, Upadhyay V, Kumar V, et al. Innate lymphoid cells facilitate NK cell development through a lymphotoxin-mediated stromal microenvironment. J Exp Med 2014; 211:1421-1431.

38. Kallaur AP, Oliveira SR, Simao ANC, et al. Tumor necrosis factor beta NcoI polymorphism is associated with inflammatory and metabolic markers in multiple sclerosis patients. J Neurol Sci 2014;346:156-163.

39. Veiga-Parga T, Giménez F, Mulik S, et al. Controlling herpetic stromal keratitis by modulating lymphotoxinalpha-mediated inflammatory pathways. Microbes Infect 2013;15:677-687. 


\section{Neurology ${ }^{\oplus}$ \\ Neuroimmunology \& Neuroinflammation}

Characterization of lymphopenia in patients with MS treated with dimethyl fumarate and fingolimod

Maryam Nakhaei-Nejad, David Barilla, Chieh-Hsin Lee, et al.

Neurol Neuroimmunol Neuroinflamm 2018;5;

DOI 10.1212/NXI.0000000000000432

This information is current as of December 28, 2017

Neurol Neuroimmunol Neuroinflamm is an official journal of the American Academy of Neurology.

Published since April 2014, it is an open-access, online-only, continuous publication journal. Copyright

Copyright $\odot 2017$ The Author(s). Published by Wolters Kluwer Health, Inc. on behalf of the American

Academy of Neurology.. All rights reserved. Online ISSN: 2332-7812.

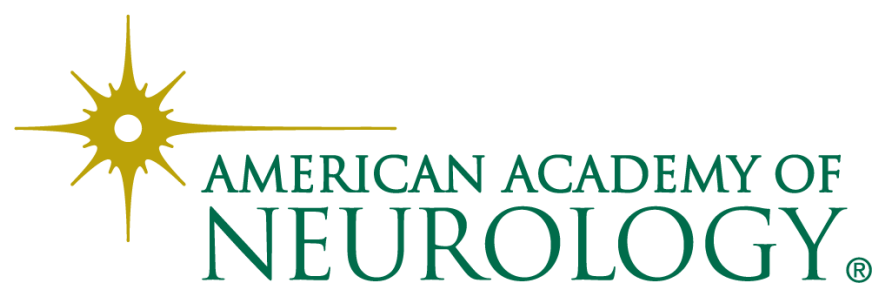




\section{Updated Information \& Services}

\section{Supplementary Material}

\section{References}

Citations

Subspecialty Collections

\section{Errata}

Permissions \& Licensing

Reprints including high resolution figures, can be found at: http://nn.neurology.org/content/5/2/e432.full.html

Supplementary material can be found at: http://nn.neurology.org/content/suppl/2017/12/28/5.2.e432.DC1

This article cites 39 articles, 6 of which you can access for free at: http://nn.neurology.org/content/5/2/e432.full.html\#\#ref-list-1

This article has been cited by 1 HighWire-hosted articles: http://nn.neurology.org/content/5/2/e432.full.html\#\#otherarticles

This article, along with others on similar topics, appears in the following collection(s):

Autoimmune diseases

http://nn.neurology.org//cgi/collection/autoimmune_diseases

Multiple sclerosis

http://nn.neurology.org//cgi/collection/multiple_sclerosis

An erratum has been published regarding this article. Please see next page or:

/content/5/2/e445.full.pdf

Information about reproducing this article in parts (figures,tables) or in its entirety can be found online at:

http://nn.neurology.org/misc/about.xhtml\#permissions

Information about ordering reprints can be found online: http://nn.neurology.org/misc/addir.xhtml\#reprintsus

Neurol Neuroimmunol Neuroinflamm is an official journal of the American Academy of Neurology.

Published since April 2014, it is an open-access, online-only, continuous publication journal. Copyright

Copyright $\odot 2017$ The Author(s). Published by Wolters Kluwer Health, Inc. on behalf of the American Academy of Neurology.. All rights reserved. Online ISSN: 2332-7812.

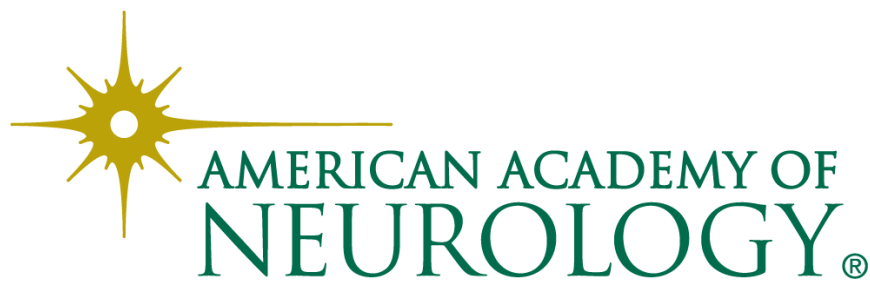




\section{Characterization of lymphopenia in patients with MS treated with dimethyl fumarate and fingolimod}

Neurol Neuroimmunol Neuroinflamm 2018;5:e445. doi:10.1212/NXI.0000000000000445

In the Article "Characterization of lymphopenia in patients with MS treated with dimethyl fumarate and fingolimod" by M. Nakhaei-Nejad et al. ${ }^{1}$, there are typographical errors in the Abstract, which should use "CD4 $4^{+”, ~ " C D 8 ~} 8^{+”, ~ " C D 27} 7^{+} \mathrm{IgD}$ ", and "CD27" rather than "CD41," "CD81," CD271IgD2," and "CD271" as originally published. The publisher regrets the errors.

\section{Reference}

1. Nakhaei-Nejad M, Barilla D, Lee CH, Blevins G, Giuliani F. Characterization of lymphopenia in patients with MS treated with dimethyl fumarate and fingolimod. Neurol Neuroimmunol Neuroinflamm 2018;5:e432. 